\title{
KAMPUNG BATIK DIGITAL BERBASIS VIRTUAL TOUR SEBAGAI WADAH PROMOSI BATIK KOTA PEKALONGAN DI ERA INDUSTRI 4.0 (Studi Kasus: Kampung Batik Banyurip)
}

\author{
Eko Budi Susanto $^{1 *}$, Rizqi Wijonarko ${ }^{2}$, Edi Purwanto ${ }^{3}$, Sattriedi Wahyu Binabar ${ }^{4}$ \\ STMIK Widya Pratama Pekalongan, Jl Patriot No 25 Pekalongan Phone 427816, \\ Korespondensi : equ_bs@gmail.com
}

\begin{abstract}
The promotion of batik products in the Pekalongan batik city needs to be carried out so that it can be better known to the community, but is constrained by the limited working hours available. On the other hand President Joko Widodo stressed that the need to create a virtual trade exhibition, so that buyers can interact without the need to wait for an exhibition or are constrained by time. To respond to the appeal of Mr. Joko Widodo, through the development of virtual reality tenology which has also given birth to virtual tour innovations, a virtual tour village based on virtual tour will be built, so that batik artisans will have more time to promote their products, as well as visitors / consumers who have not had time to come to the batik village, will still be able to see the atmosphere of the existing batik village by accessing the digital batik village application of Pekalongan batik city based on virtual tour, and keep interacting with Pekalongan batik craftsmen, whenever and wherever. The application of this research will have a positive impact on several parties, namely: 1) batik artisans, 2) visitors / consumers, and 3) Pekalongan city government. The existence of digital batik villages based on virtual tours will be a new breakthrough / new paradigm in creating and managing batik villages so that they can be visited from anywhere and anytime.
\end{abstract}

Keywords: Batik Village, Digital, Virtual Tour

\section{PENDAHULUAN}

Era Industri 4.0 internet dan komputer telah menjadi bagian penting dari semua aspek kehidupan sehari-hari, seperti: bekerja, berkomkunikasi, belajar, hiburan, belanja dan lain-lain. Pemasaran digital menjadi strategi utama bagi manajemen untuk melakukan promosi atau pemasaran. Hal tersebut menjadi perhatian serius Presiden Republik Indonesia, bapak Joko Widodo, seperti yang disampaikan di Indonesia Convention Exhibition (ICE) BSD, Tangerang, Banten,pada hari Rabu (11/10/2017), "Antisipasi terhadap pergeseran perdagangan dari offline ke online. Perubahan digital sudah tidak bisa dilawan, dan harus dirangkul untuk meningkatkan perdagangan kita," Menurut Jokowi, salah satu yang bisa dilakukan adalah dengan membuat pameran perdagangan virtual. Dengan begitu, para pembeli (buyer) dapat berinteraksi tanpa perlu menunggu adanya pameran. "Kita kenapa tidak buat virtual showroom, jadi interaksinya bisa langsung tanpa harus menunggu expo," (Detik.com 2017), demikian himbauan beliau.

Kota Pekalongan yang merupakan kota batik, memiliki beberapa kampung batik yang sebagian besar warganya berprofesi sebagai pengusaha batik. Keberadaan kampung batik tersebut, selain menjadi sentra pengratin batik juga menjadi salah satu destinasi wisata nasional yang dapat meningkatkan pendapatan baik bagi warganya maupun bagi Pemerintah Kota Pekalongan.

Salah satu cara untuk melakukan pemasaran digital yang dapat menginformasikan produk dan lokasi/kota adalah dengan mewujudkan kampung batik digital berbasis virtual tour. Sehingga apabila tersedia kampung batik digital berbasis virtual tour, maka para pengrajin batik akan memiliki waktu yang lebih panjang untuk mempromosikan produkproduknya (tidak terkendala jam kerja), serta konsumen yang belum sempat datang ke 
kampung batik, tetap dapat melihat suasana kampung batik yang ada dengan mengakses aplikasi kampung batik digital berbasis virtual tour yang tersedia.

Dari beberapa penelitian yang sudah dilakukan (Suhendar dan Fernando 2016), (Choiron dan Lesmana 2017), (Kusniyanti dan Fendra t.thn.), (Susanto, Wijanarto dan WM 2014), maka dapat diketahui bahwa pemanfaatan virtual tour di beberapa tempat tersebut, telah memberikan dampak yang positif seperti: Mampu menjadi bagian dari media promosi yang lebih atraktif, mampu membuat pengguna seolah melihat dan bergerak ditempat tersebut, mampu membantu seseorang dalam membentuk pengalaman berkunjung ke suatu tempat, mampu menarik minat pengunjung untuk mengunjungi museum secara langsung. Akan teteapi dari beberapa penelitian yang telah dilakukan tersebut belum terlihat penerapan virtual tour pada ruang pamer digital produk-produk industri kreatif, yang juga memungkinkan adanya interaksi antara pelaku industri kreatif dengan konsumen. Jika hal tersebut dapat terwujud, tentunya akan memberikan dampak positif bagi perkembangan industri kreatif di Indonesia.

Untuk itu pada penelitian ini akan dibangun kampung batik digital berbasis virtual tour sebagai wadah promosi batik Kota Pekalongan di era industri 4.0.

\section{TINJAUAN PUSTAKA}

\subsection{Virtual Tour}

Virtul tour merupakan simulasi dari tempat atu lokasi yang sebenarnya, merupkan serangkaian foto atau video yang dikombinaksikan dengan sound effect, musik, teks atau narasi. Virtual tour disebut juga panoramic tour. Panorama dapat diartikan sebagai pandangan yang tidak terputus, karena panorama berupa kumpulan foto yang memanjang atau dapat berupa pengambilan video yang kamerannya berputar/bergeser (Thomas, Sompie dan Sugiarso 2018). Beberapa tempat virtual tour yang paling terkenal adalah museum, tempat wisata, kampus/tempat pendidikan, real estate dan tempat-tempat umum yang terkenal.

\subsection{Multimedia}

Multimedia terdiri dari dua kata, yaitu: multi yang berarti banyak, media yang berarti alat perantara. Dengan demikian multimedia dapat diartikan banyak media. Multimedia merupakan kombinasi dari media teks, gambar, suara, animasi, dan video yang terintegrasi dalam komputer (Vaughan 2004). Virtual tour dapat dikatakan sebagai salah satu bidang multimedia. Di dalam virtual tour terdapat gabungan unsur-unsur multimedia yang terdiri dari teks, gambar, suara, animasi, serta video. 


\subsection{Kerangka Pikir}

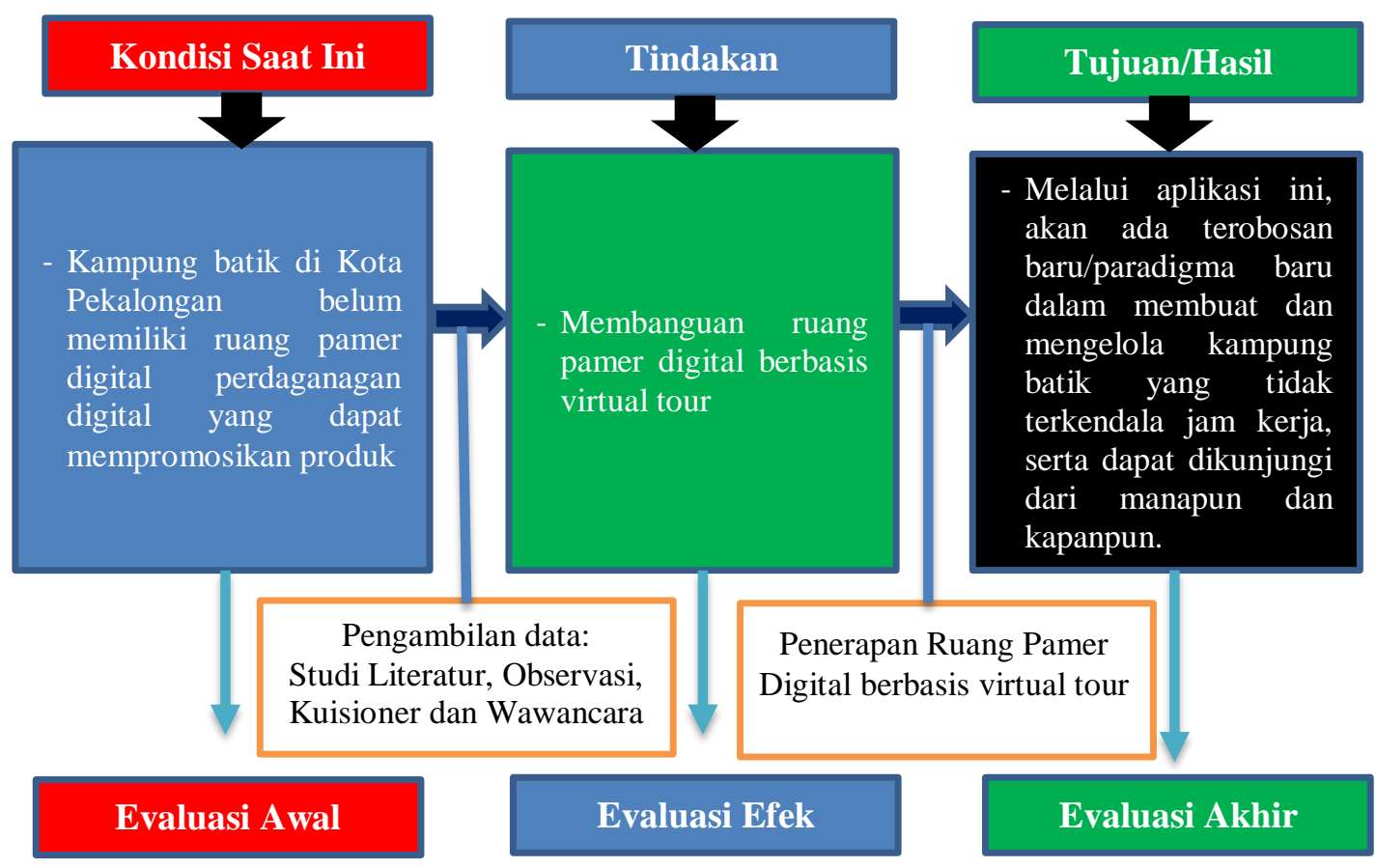

Gambar 1 Kerangka Pikir

\section{METODE PENELITIAN}

\subsection{Metode Pengumpulan data}

Merupakan pengumpulan bahan baku untuk memberikan gambaran spesifik mengenai obyek penelitian dengan menggunakan beberapa teknik berikut ini:

a) Teknik Studi Lapangan

Data diperoleh melalui pengamatan terhadap kegiatan-kegiatan yang terkait. Seperti pengambilan gambar/video, dan bahan-bahan lainnya

b) Teknik Studi Literatur

Data diperoleh melalui beberapa referensi/jurnal yang terkait.

c) Teknik Wawancara

Data diperoleh dari hasil wawancara dengan narasumber yang terkait, yaitu beberapa pengrajin batik di Kampung Batik Banyurip, Kepala Kelurahan Banyurip Kota Pekalongan.

d) Teknik Penyebaran Kuisioner

Data diperoleh dari hasil rekapitulasi kuisioner yang disebarkan ke responden yaitu para pengrajin batik di Kampung Batik Banyurip dan masyarakat.

\subsection{Metode Pengembangan Sistem Multimedia}

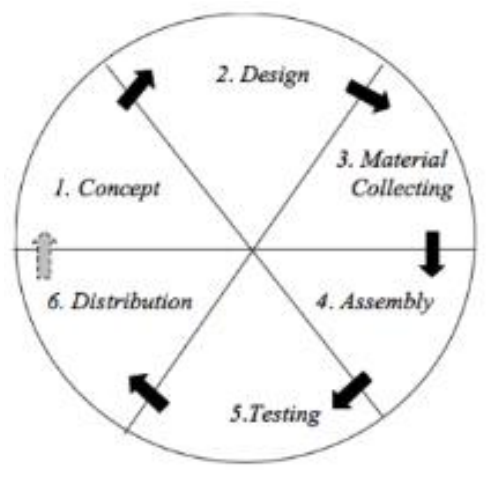

Gambar 2 Kerangka Pikir 
Metode pengembangan sistem multimedia terdiri dari enam tahapan, yaitu: konsep, desain, pengumpulan bahan, pembuatan, pengujian dan distribusi (Hadi 2003).

a) Konsep

Tahap ini dilakukan penentuan kebutuhan fungsional dan non fungsional sistem bedasarkan kebutuhan pengguna dan hasil pengumpulan data.

b) Desain

Pada tahap ini akan didesain desain alur sistem, desain interface sistem, desain database sistem menggunakan alat pengembangan sistem.

c) Pengumpulan Bahan

Pengumpulan bahan/konten aplikasi/sistem multimedia yang akan dibangun, seperti: materi, gambar, video, sound dan data-data lain yang dibutuhkan

d) Pembuatan

Pada tahap pembuatan akan dibangun aplikasi/sistem multimedia berdasarkan desain yang telah dibuat.

e) Pengujian

Pada tahap ini akan digunakan metode alpha test dan betha test untuk menguji aplikasi/sistem multimedia

f) Distribusi

Pada tahap ini dilakukan implementasi aplikasi/sistem kepada pengguna,

\section{Hasil dan Pembahasan} dengan cara meng-onlinekan aplikasi/sistem multimedia

\subsection{Pengumpulan Data}

Pengumpulan data dilakukan untuk mengetahui kebutuhan fungsional dan non fungsional sistem. Beberapa teknik yang dilakukan dalam pengumpulan data antara lain:

\subsubsection{Observasi/Survey/Studi Lapangan}

Observasi dilakukan di Kampung Batik Banyurip Kota Pekalongan, dengan cara melakuan survei tempat/lapangan terkait kondisi atau letak Kampung Batik Banyurip Kota Pekalongan. Observasi yang dilakukan yaitu dengan cara pengambilan gambar dengan foto 360. Alat yang digunakan adalah kamera YIVR 360 Canon. Pengambilan foto dilakukan satu per satu sesuai dengan rumah atau showroom para pengrajin batik di Kampung Batik Banyurip.

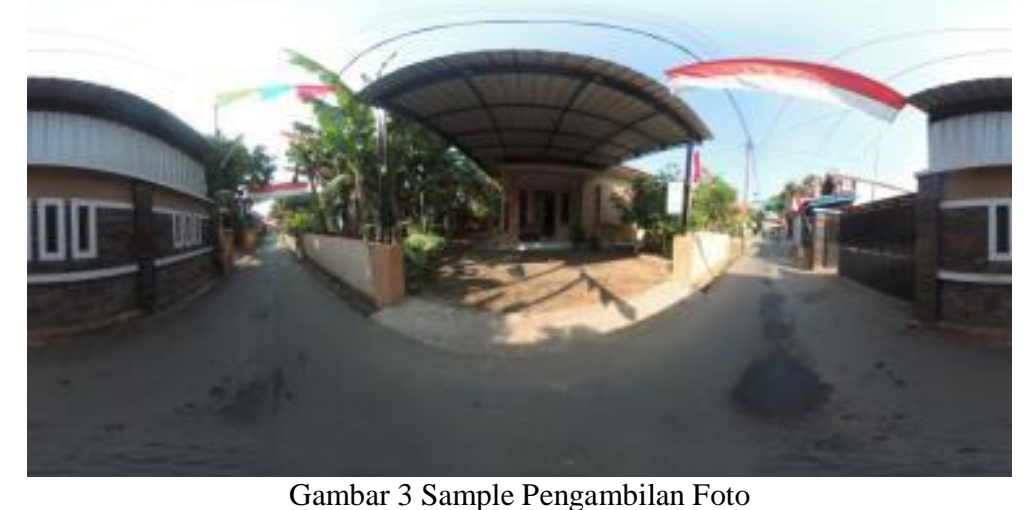

Selain melakukan pengambilan gambar, dilakukan juga pengambilan data berupa nama dan alamat pengrajin batik di Kampung Batik Banyurip. Data didapatkan dari Kelurahan Banyurip. Dari data tersebut didapatkan sebanyak 35 (tiga puluh lima) pengrajin batik. 


\subsubsection{Wawancara}

Wawancara dilakukan dengan beberapa pihak terkait, diantaranya dengan Kepala Kelurahan Banyurip Kota Pekalongan Bapak "H. Sudaryo, S.H”. Dari hasil wawancara dengan Kepala Kelurahan Banyurip didapat bahwa: Internet telah menjangkau dan dapat diakses di wilayah Kelurahan Banyurip. Masyarakat di Kampung Batik Banyurip telah menggunakan internet akan tetapi sebagian besar warga belum memanfaatkan internet untuk mengelola bisnis batiknya. Untuk mempromosikan usaha, para pengrajin batik di Kampung Batik Banyurip ikut serta di berbagai event dan pameran batik di Kota Pekalongan. Kelurahan Banyurip pada dasarnya telah menyediakan toko online secara kolektif bagi masyarakat. Namun yang menggunakan hanya beberapa saja. Selebihnya mereka memanfaatkan marketplace yang ada secara mandiri seperti Tokopedia, Bukalapak, Lazada, dll. Harapan dengan akan dibangunnya Kampung Batik Digital Berbasis Virtual Tour menurut beliau yaitu dapat mendatangkan wisatawan dari luar Kota Pekalongan, sehingga dapat meningkatkan promosi dan pendapatan warga di Kampung Batik Banyurip

Wawancara juga dilakukan kepada lima pengusaha batik yang mewakili dari pengrajin batik Kampung Batik Banyurip. Dari hasil wawancara dengan pengrajn batik didapatkan bahwa: beberapa pengrajin sudah melakukan pemasaran dengan memanfaatkan media internet untuk melakukan pemarasan secara online. Cakupan wilayah pemasarannya, beberapa sudah ke luar Kota Pekalongan bahkan ada yang ke luar negeri. Mereka melakukan pemasaran secara online menggunakan media sosial seperti Tellegram, Facebook, Market Place. Adapun harapan dengan akan dibangunnya Kampung Batik Digital Berbasis Virtual Tour menurut mereka yaitu Kampung Batik Digital Berbasis Virtual Tour dapat membantu pemasaran produk-produk dari pengrajin batik dengan menampilkan lokasi, gambar produk, kontak person, dan link media sosial atau marketplace yang mereka miliki.

\subsubsection{Kuesioner}

Kuesinoer dibagikan kepada masyarakat umum dengan tujuan untuk mengetahui keberadaan Kampung Batik Banyurip di kalangan masyrakat umum. Kuesioner dibagikan dengan memanfaatkan fasilitas dari google form. Penyebaran kuesioner dilakukan selama lima hari dari tanggal 3 Oktober sampai dengan 7 Oktober 2019. Hasilnya didapatkan sebanyak 75 responden yang mengisi kuesioner tersebut.

Berikut ini adalah daftar pertanyaan dan jumlah jawaban kuesioner yang didapat:

\begin{tabular}{|c|l|c|c|c|c|c|c|}
\hline \multirow{2}{*}{ No } & \multicolumn{1}{|c|}{ Pertanyaan } & \multicolumn{2}{|c|}{ Ya } & \multicolumn{2}{c|}{ Tidak } & \multicolumn{2}{c|}{ Total } \\
\cline { 2 - 7 } & \multicolumn{1}{|c|}{ Jml } & $\%$ & $\mathrm{Jml}$ & $\%$ & $\mathrm{Jml}$ & $\%$ \\
\hline 1 & $\begin{array}{l}\text { Apakah Anda pernah berkunjung ke Kampung } \\
\text { Batik Banyurip? }\end{array}$ & 30 & $40 \%$ & 45 & $60 \%$ & 75 & $100 \%$ \\
\hline 2 & $\begin{array}{l}\text { Apakah Anda pernah belanja di Kampung } \\
\text { Batik Banyurip? }\end{array}$ & 25 & $33 \%$ & 50 & $67 \%$ & 75 & $100 \%$ \\
\hline 3 & $\begin{array}{l}\text { Apakah Anda pernah mengajak teman luar } \\
\text { kota berkunjung ke Kampung Batik Banyurip? }\end{array}$ & 22 & $29 \%$ & 53 & $71 \%$ & 75 & $100 \%$ \\
\hline 4 & $\begin{array}{l}\text { Apakah Anda kesulitan mendapatkan } \\
\text { gambaran Kampung Batik Banyurip? }\end{array}$ & 27 & $36 \%$ & 48 & $64 \%$ & 75 & $100 \%$ \\
\hline 5 & $\begin{array}{l}\text { Apakah Anda setuju jika dibuatkan Virtual } \\
\text { Tour untuk gambaran Kampung Batik } \\
\text { Banyurip? }\end{array}$ & 73 & $97 \%$ & 2 & $3 \%$ & 75 & $100 \%$ \\
\hline 6 & $\begin{array}{l}\text { Apakah Anda setuju bila Virtual Tour yang } \\
\text { dibuat dapat melakukan transaksi produk } \\
\text { melalui link marketplace atau media sosial? }\end{array}$ & 67 & $89 \%$ & 8 & $11 \%$ & 75 & $100 \%$ \\
\hline
\end{tabular}




\subsubsection{Konsep}

Pada tahap ini akan dilakukan analisa dari hasil pengumpulan data untuk didapatkan kebutuhan fungsional dan non-fungsional sistem.

Berikut ini adalah Kebutuhan Fungsional Sistem:

a) Aplikasi dapat memvisualisasikan kondisi lingkungan di Kampung Batik Banyurip Kota Pekalongan

b) Aplikasi dapat menampilkan tempat/rumah/show room para pengrajin batik di Kampung Batik Banyurip Kota Pekalongan

c) Aplikasi dapat menampilkan informasi atau link dari marketplace para pengrajin batik di Kampung Batik Banyurip Kota Pekalongan

d) Aplikasi dapat memberikan pengetahuan atau informasi seputar batik Kota Pekalongan

Berikut ini adalah kebutuhan non-fungsional sistem:

a) Tersedianya tombol navigasi pada aplikasi

b) Aplikasi dapat berjalan baik di komputer/PC ataupun di smartphone

c) Tampilan aplikasi responsive

\subsubsection{Hasil Analisa Pengumpulan Data}

Dari hasil pengumpulan data yang dilakukan dapatkan bahwa: Terdapat sebanyak 35 (tiga puluh lima) pengrajin batik di Kampung Batik Banyurip Kota Pekalongan. Beberapa pengrajin batik dalam mempromosikan usaha, melalui berbagai event dan pameran batik di Kota Pekalongan. Beberapa pengrajin batik melakukan pemasaran secara online menggunakan media sosial seperti Tellegram, Facebook, Market Place (tokopedia, lazada, shopee, dll). Cakupan wilayah pemasarannya, beberapa sudah ke luar Kota Pekalongan bahkan ada yang ke luar negeri. Kampung Batik Banyurip kurang dikenal oleh masyarakat.

\subsection{Desain}

\subsubsection{Desain Alur Sistem}

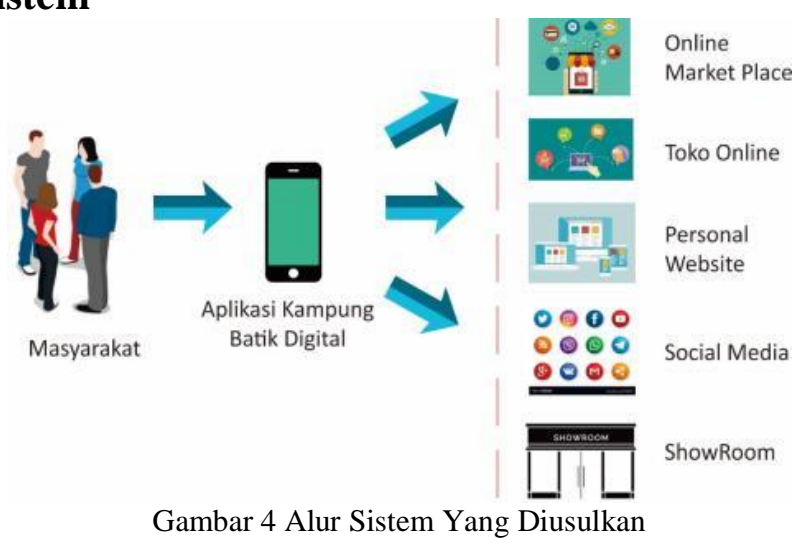

Masyarakat atau pengguna dapat mengunjungi aplikasi kampung batik digital melalui smart phone, di dalam aplikasi tersebut akan dapat ditampilkan virtual tour dari Kampung Batik Banyurip. Melalui aplikasi tersebut masyarkat dapat menjelajahi layaknya berkunjung ke Kampung Batik Banyurip, masyarakat dapat melihat seolah-olah berada di tempat kampung batik, seperti pada kondisi sebenarnya.

Berbeda dengan virtual tour yang lainnya, aplikasi Kampung Batik Digital Berbasis Virtual Tour ini dapat menampilkan link atau alamat online media pemasaran dari pengrajin batik yang ada di Kampung Batik Banyurip (marketplace, toko online, personal web, social media, showroom). Sehingga diharapkan dengan, tanpa harus susah payah untuk pergi ke tempat yang sebenarnya masyarakat dapat melihat produk dan melakukan transaksi pembelian produk batik. 


\subsubsection{Desain Struktrur Menu}

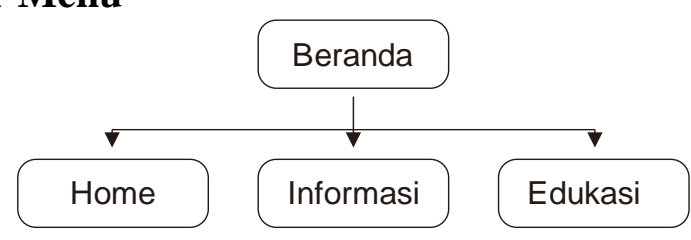

Gambar 5 Desain Struktur Menu

Aplikasi Kampung Batik Digital terdiri dari tiga menu utama, yaitu: Menu Home, berisi tentang virtual tour kampung batik. Menu Informasi berisi tentang informasi aplikasi kampung batik digital, Menu Edukasi, berisi tentang pengetahuan seputar batik Kota Pekalongan

\subsubsection{Desain Interface}

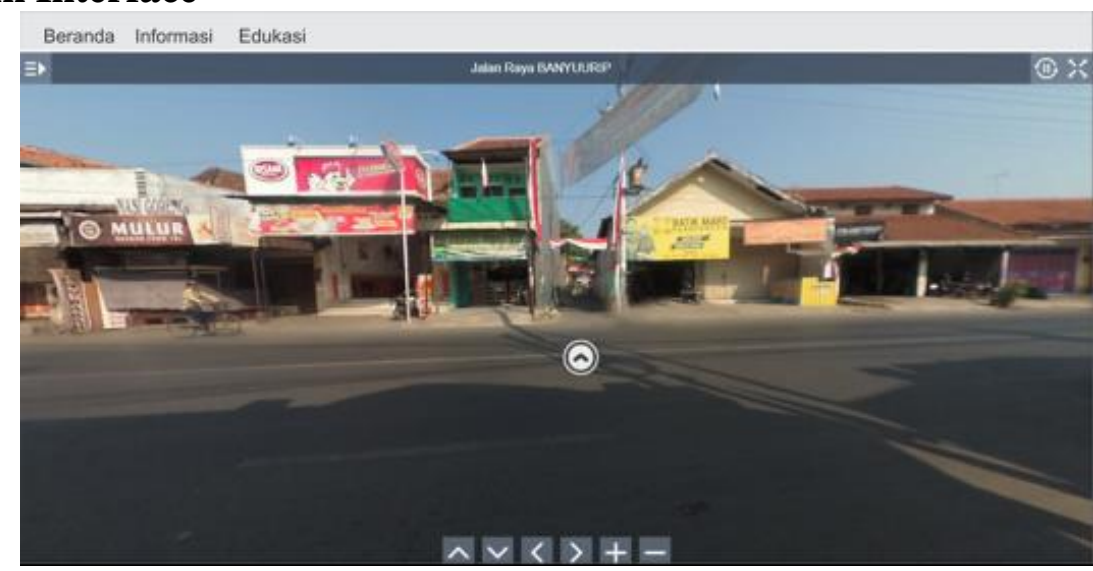

Gambar 6 Desain Interface Kampung Batik Digital

Pada halaman beranda terdiri dari tiga menu utama, yaitu: Menu Beranda digunakan untuk menuju ke halaman virtual tour. Menu Informasi berisi tentang informasi seputar Kampung Batik Banyurip. Menu Edukasi berisi tentang pembelajaran tentang batik.

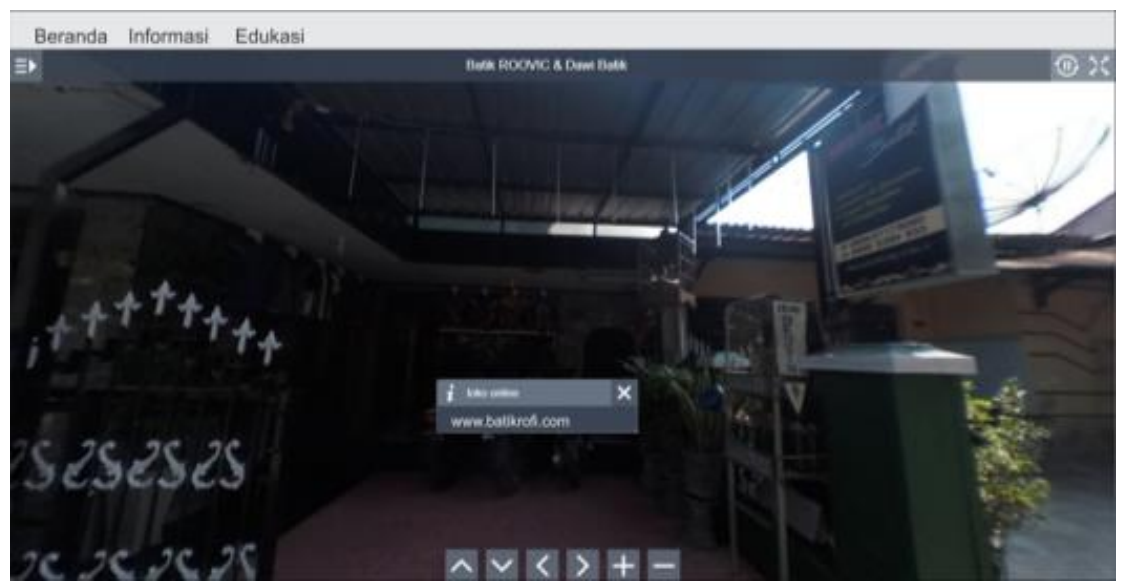

Gambar 7 Desain Interface Saat Virtual Tour Menuju Rumah Pengrajin Batik

Melalui virtual tour pengguna dapat menjelajahi virtual tour kampung dengan menggunakan navigasi yang telah disediakan. Navigasi berupa simbol panah yang dapat menuju ke tempat pengrajin batik yang dituju. Pada halaman tempat pengrajin batik, terdapat informasi tentang alamat link pemasaran yang dapat dituju oleh pengguna. 


\subsection{Pengumpulan Bahan}

Pengumpulan bahan yang dilakukan yaitu melakukan pengambilan gambar tiap-tiap node atau tempat di Kampung Batik Banyurip. Pengambilan data dilakukan dengan kamera 360 YIVR 360 Canon. Setelah gambar terkumpul tahap selanjutnya adalah pembuatan.

\subsection{Pembuatan}

Setalah bahan gambar terkumpul, langkah selanjutnya sebelum dilakukan pengkodean, terlebih dahulu hasil foto dilakukan proses editing. Proses editing foto menggunakan perangkat lunak pengolah gambar bitmap Adobe Photoshop.

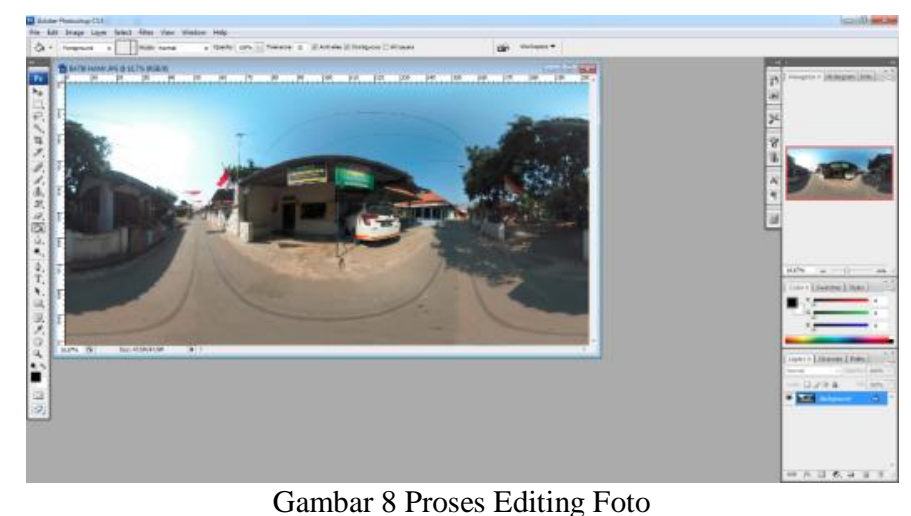

Sedangkan pengkodean menggunakan bahasa pemrograman berbasis web, seperti: javascitpt, framework bootstrap, framework codeigneter, JSON (JavaScript Object Notation). Proses pembuatan kampung batik digital berbasis virtual tour menggunakan library marzipano.

\subsection{Pengujian}

Tahap berikutnya yaitu menguji aplikasi menggunakan pengujian Black Box Testing untuk mengetahui sejauh mana aplikasi ini dapat berjalan dengan baik sesuai fungsionalitas. Hasilnya adalah semua kinerja fungsi dapat berjalan dengan baik diantaranya fungsi tombol untuk memilih toko batik yang diinginkan, tombol untuk menjelajahi kampung batik secara virtual, masuk ke showroom toko batik dan link marketplace yang digunakan oleh pengusaha toko batik.

\subsection{Distribusi}

Di tahap akhir sistem aplikasi yang sudah jadi kemudian disebarluaskan ke masyarakat melalui website dengan alamat https://tourbatik.stmik-wp.com/. Pada website tersebut masyarakat dapat menjelajahi virtual tour kampung batik secara bebas dan dapat melakukan transaksi langsung dengan penjual batik secara online.

\subsection{Bentuk Prototipe}

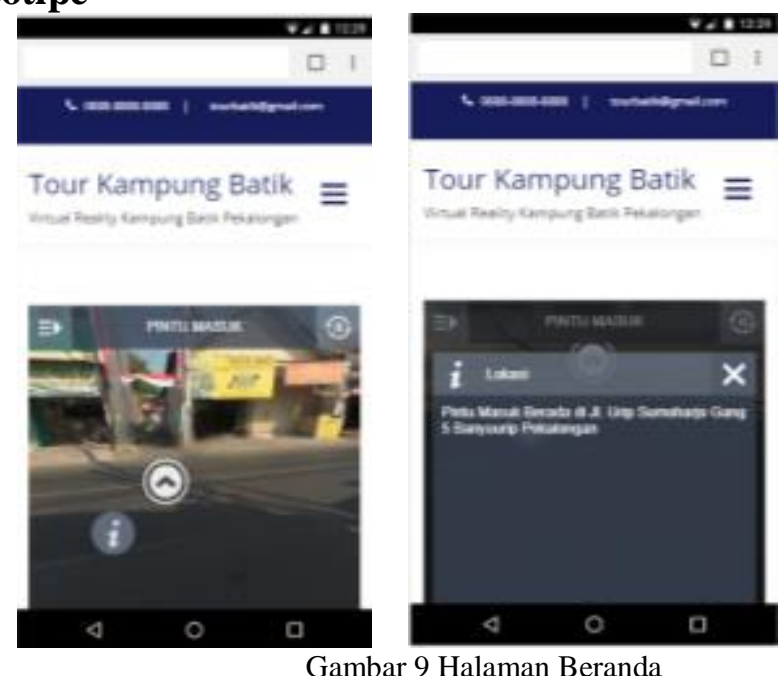

Gambar 9 Halaman Beranda 
Halaman beranda berisi tentang menu kampung batik digital yang langsung dapat diakses dengan menggunakan tombol-tombol navigasi yang sudah disediakan. Tanda panahdigunakan untuk menuju arah yang dituju, tanda simbol "i” berisi informasi marketplace yang tersedia.

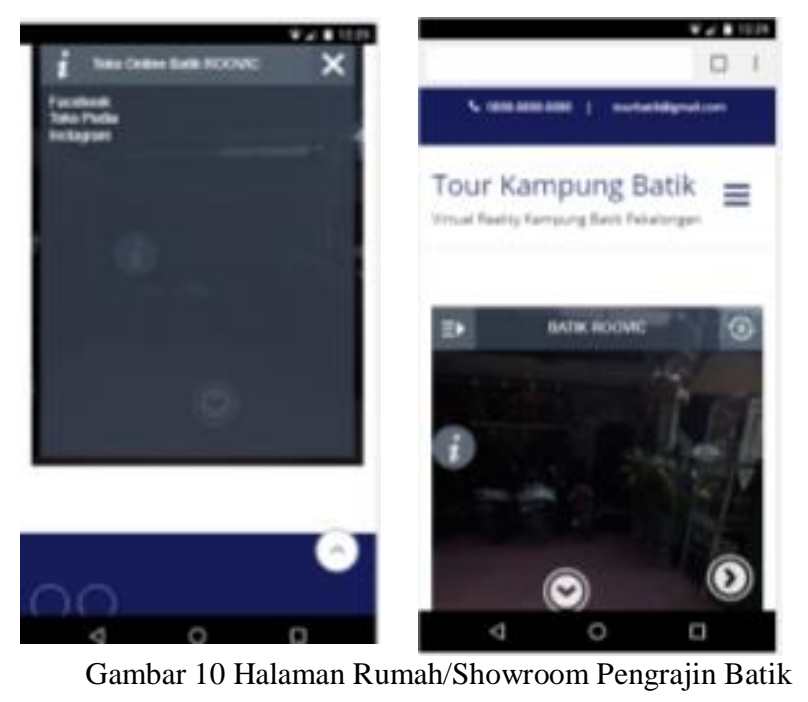

Pengunjung dapat menjelajahi kampung batik digital dengan menggunakan navigasi yang tersedia, dan dapat melihat rumah/showroom pengrajin batik melalui tombol informasi yang tersedia. Melalui tombol informasin tersebut pengunjung dapat melihat marketplace yang dimiliki oleh pengrajin batik.

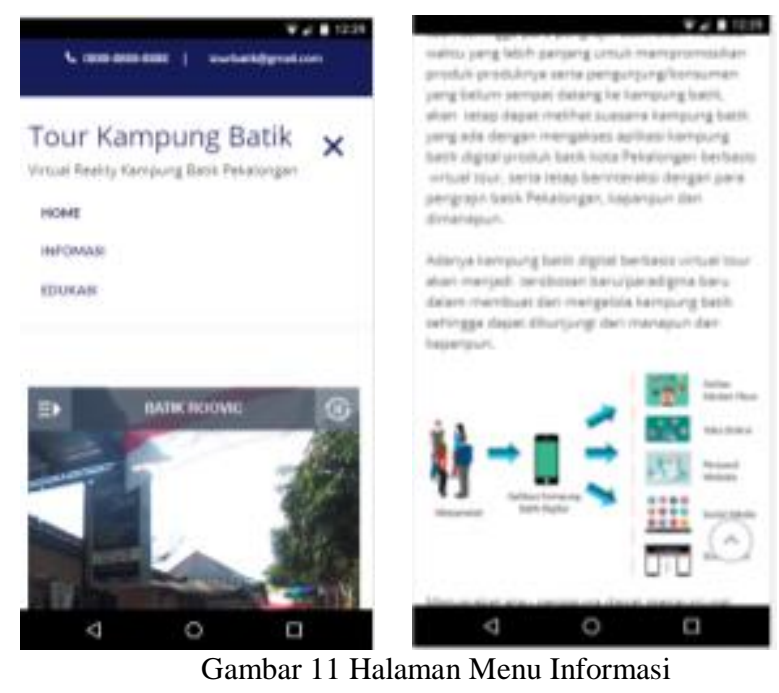

Halaman Menu Informasi berisi tentang informasi Kampung Batik Digital, melalui menu informasi ini pengunjung dapat mengetahui cara kerja dari aplikasi kampung batik digital. 


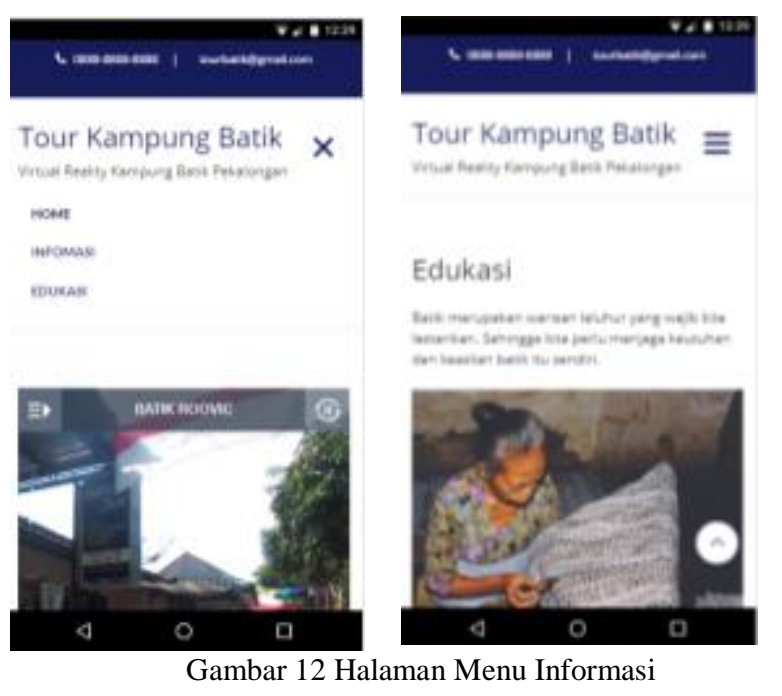

Halaman Menu Edukasi berisi tentang pengetahuan seputar batik, pada menu ini pengunjung dapat mempelajari cara membedakan batik asli dan kain printing tekstil bermotif batik, serta dapat mengetahui corak motif batik Kota Pekalongan

\section{Kesimpulan dan Saran}

\subsection{Simpulan}

Dari hasil pengujian aplikasi kampung batik digital yang dilakukan dapat disimpulkan bahwa aplikiasi kampung batik digital telah sesuai dengan kebutuhan fungsional dan non fungsional yang diharapkan.

Aplikasi kampung batik digital dapat menampilkan atau memvisualisasikan kondisi lingkungan yang sebenarnya di Kampung Batik Banyurip Kota Pekalongan sebagai obyek penelitian. Aplikasi kampung batik digital dapat menampilkan informasi atau link marketplace yang dimiliki oleh para pengrajin batik di Kampung Batik Banyurip Kota Pekalongan. Aplikasi kampung batik dapat memeberikan unsur edukasi kepada masyarakat atau pengunjung tentang batik asli dan batik khas Kota Pekalongan.

Tidak hanya menjelajah secara virtual, pengunjung juga dapat bertransaksi dengan penjual batik, sehingga hal ini dapat menjadikan kemudahan yang nyata bagi masyarakat di dalam perkembangan Era Industri 4.0.

\subsection{Saran}

Karena wilayah yang terbatas, maka untuk penelitian berikutnya dapat dilakukan perluasan jangkauan wilayah dalam objek penelitian. Selain itu untuk pengembangan selanjutnya aplikasi kampung batik digital sebaiknya dapat memberikan informasi atau membedakan produk-produk batik asli dan kain baik bermotif teksil, agar para pengunjung dapat mengetahui jenis batik yang diproduksi oleh para pengrajin batik di Kampung Batik Banyurip.

Selain itu, perlu dilakukan penyempurnaan konten seperti dengan menambahkan video profil Batik Pekalongan, informasi tour guide, penambahan baksound untuk menghidupkan kekuatan Virtual Tour, serta melengkapi konten atau ini pada menu edukasi seputar pengetahuan tentang batik di Kota Pekalongan.

Hasil penelitian ini dapat menjadi masukan untuk Pemerintah Kota Pekalongan, untuk bisa mendorong para pengusaha batik untuk lebih siap menghadapai era industri 4.0 dan tetap mempertahankan batik sebagai ciri khas dan kekuatan Kota Pekalongan di tengah persaingan global yang tidak mungkin dihindari lagi 


\section{DAFTAR PUSTAKA}

Choiron, Achmad, dan Irfian Lesmana. "Aplikasi Virtual Tour Dinamis Pada Universitas Dr. Soetomo Surabaya Berbasis Web.” Jurnal Inform Vol.2 No.1, Januari 2017, ISSN : 2502-3470, Januari 2017.

Detik.com. https://finance.detik.com/berita-ekonomi-bisnis/d-3679331/jokowi-perubahan-digital-takbisa-dilawan-harus-dirangkul. diakses pada 23 Maret 2019, 2017.

Hadi, Sutopo Ariesto. Multimedia Interaktif dengan Flash. Yogyakarta: Graha Ilmu, 2003.

Kusniyanti, Harni, dan Fendra. "Aplikasi Virtual Museum Berbasis Tiga Dimensi." Jurnal Ilmiah FIFO, ISSN 2085-4315, April 2016.

Suhendar, Akip, dan Aditya Fernando. "Aplikasi Virtual tour Berbasis Multimedia Interaktif Menggunakan Autodesk 3Ds Max." Jurnal ProTekInfo Vol. 3 No. 1 September 2016, ISSN: 2406-7741, September 2016.

Susanto, Ajib, Wijanarto, dan Ibnu Utomo WM. "Rekayasa e-Market untuk Kelompok Usaha Pemuda Binaan Dinas Pemuda dan Olahraga Propinsi Jawa Tengah sebagai Upaya Peningkatan Pemasaran dan Penjualan Produk ." Prosiding SNATIF Ke-1 Tahun 2014, ISBN: 978-6021180-04-4. 2014.

Thomas, Dianto G., Sherwin R. U. A. Sompie, dan Brave A. Sugiarso. "Virtual Tour Sebagai Media Promosi Interaktif Penginapan Di Kepulauan Bunaken.” E-Journal Teknik Informatika Vol. 13, No. 1 (2018) ISSN : 2301-8364, 2018.

Vaughan, Tay. Multimedia : Making it Work. Edisik ke 6. Yogyakarta: Andi Offset, 2004. 